\title{
BIOCHEMICAL NORMALIZATION OF TRACE METALS IN ARCTOCEPHALUS AUSTRALIS
}

\author{
Besnik Baraj, Luis Felipe Niencheski, Gilberto Fillmann and Luciano Hermanns
}

Fundação Universidade Federal do Rio Grande (Caixa Postal 474, 96201-900 Rio Grande, RS, Brasil)

dqmhidro@furg.br

\section{A B S T R A C T}

Initially, the heart concentration data does not seem relevant for use as a bioindicator, mainly due to its low concentration level. After applying a normalizing procedure, the heart results were a better $\mathrm{Hg}$ bioindicator (preconcentration coefficient 43.1) than those of the kidney (preconcentration coefficient 8.6). Cadmium preconcentration coefficients were 128.1, 195.3 and 5.2 for liver, kidney and heart, respectively, demonstrating the high accumulative capacity especially for the liver and kidneys. Iron is proposed as a normalizing element for the definiton of the regional natural biochemical population of the metals. In general, positive correlation coefficients were found between Fe and other metals.

\section{RES UMO}

Arctocephalus australis foi usado como organismo indicador para concentrações de metal traço na costa do Rio Grande do Sul. Metais foram analisados em tecidos extraídos do coração, rins e fígado. Os baixos teores encontrados no coração inicialmente poderiam indicar que este órgão não traria resultados relevantes. Porém, mediante a aplicação de um procedimento de normalização, foram encontrados coeficientes de pré-concentração de 43.1 e de 8.6 para o coração e para os rins, respectivamente, indicando o tecido do coração como o melhor bioindicador para $\mathrm{Hg}$. Para $\mathrm{Cd}$, os coeficientes de pré-concentração foram 128.1, 195.3 e 5.2 para fígado, rins e coração, respectivamente, demonstrando alta capacidade acumulativa especialmente para fígado e rins. Foram encontradas altas correlações positivas entre o $\mathrm{Fe}$ e os metais $\mathrm{Zn}, \mathrm{Cu}, \mathrm{Cd}, \mathrm{Hg}, \mathrm{Ag}, \mathrm{Mn}, \mathrm{Ni}, \mathrm{Cr}$ e $\mathrm{Pb}$, indicando ser este elemento normalizante para definição da concentração bioquímica natural de metais na população de Arctocephalus australis no extremo sul do Brasil.

Descriptors: Heavy Metals, Arctocephalus australis, Normalization, Brazil Descritores: Metais Traço, Arctocephalus australis; Normalização, Brasil.

\section{INTRODUCTION}

Sediment and water analyses do not provide adequate information regarding the amount of metal which is incorporated by the biomass. The criterion that indicates heavy metal contamination is the increased metal content of the organisms as compared to that of their metal natural background. Essential trace metals, such as $\mathrm{Cu}, \mathrm{Fe}, \mathrm{Zn}$, Co etc, have important biological functions in an organism and their content can be regulated by homeostatic control mechanisms. However, when the nutritional supply becomes excessive the homeostatic mechanisms cease to function and the essential heavy metals act either in an acute or chronically toxic manner. Marine mammals are top predators, and have great potential to accumulate toxic substances associated with continental coastal waters (TANABE et al. 1994). Research beginning as early as the 1970s has shown bioaccumulation of organic and inorganic substances that have been routinely reported since then (BECKER, 2000).

The South American fur seal, Arctocephalus australis, is one of the most widely distributed otariid seals in the Southern Hemisphere (FAO, 1979). The otariid colonial breeding sites begin in the south of Brazil, extend round Cape Horn and up to Peru (MAJLUF, 1992). It is long lived, with an estimated maximum age of 25-30 years for females and 15-20 years for males (LIMA; PAEZ , 1995, 1997).

Reviews of past studies of contaminants in marine mammals indicate that the organs and tissues most commonly collected for analysis are the liver and kidney, followed by other organs such as muscles, heart, bone, skin and brain (BECKER, 2000). Chemical analysis of their tissues are useful in determining whether bioaccumulation of contaminants and potential biological effects associated with human industrial activities are occurring in the marine food web.

Tissue samples were collected from eight dead juveniles of Arctocephalus australis found stranded on the southern coast of Brazil.

\section{SAMPLING}

The specimens of the South American fur seal (Arctocephalus australis) were collected on the southeastern coast of Brazil (Fig. 1). The liver, kidney and heart of eight seals (5 females and 3 males) found 
stranded were analyzed for heavy metals. The biological parameters of the eight South American fur seals are shown in the Table 1. Only dead animals were collected. The animals were dissected in the laboratory and samples were stored at $-20{ }^{\circ} \mathrm{C}$ until analysis.

There is a strong indication that the collected organisms transited $\pm 800 \mathrm{~km}$ from the most easterly point of Uruguay (Punta del Este), which is within the northern area of the wide outer region of the La Plata Estuary, up to Torres, Brazil (Fig. 1). Since this area is located between the La Plata Estuary and the Patos Lagoon, the organisms must have received the influence of these estuaries. The organisms were found on the Cassino Beach that is located adjacent to Rio Grande city, one of the most important harbors in Brazil.

Reagents, Apparatus and Chemical Analysis

The organs were analyzed for $\mathrm{Fe}, \mathrm{Zn}, \mathrm{Cu}$, $\mathrm{Mn}, \mathrm{Cd}, \mathrm{Hg}, \mathrm{Pb}, \mathrm{Ag}, \mathrm{Ni}$ and $\mathrm{Cr}$. The sample, about 1 to $2 \mathrm{~g}$ of wet weight, was digested with $5 \mathrm{~mL} \mathrm{HNO}_{3}$ in Teflon vials, heated to $100^{\circ} \mathrm{C}$ until a transparent solution was obtained. The digestate was transferred into a $25 \mathrm{~mL}$ flask. Prior to $\mathrm{Hg}$ determination, an aliquot of the digested sample was treated with $\mathrm{BrCl}$ to oxidize and convert into inorganic any organic form of mercury (M.E.S.L., I.A.E.A., 1997). A laboratory constructed cold vapor system, coupled with an atomic absorption spectrophotometer CG-AA 7000 was used for $\mathrm{Hg}$ determination.

Samples with high concentrations of $\mathrm{Cu}, \mathrm{Fe}$, $\mathrm{Mn}, \mathrm{Zn}$ and $\mathrm{Cd}$ were determined in an air- $\mathrm{C}_{2} \mathrm{H}_{2}$ flame using a CG-AA 7000 AAS instrument. A ZEISS-5 was used in electrothermal atomization mode for $\mathrm{Cd}$, $\mathrm{Ag}, \mathrm{Ni}, \mathrm{Cr}$ and $\mathrm{Pb}$ analysis. Accuracy of analytical results was checked by analyzing a reference standard, Tuna 350 (from M.E.S.L, IAEA, Monaco). Results obtained were in close agreement with the certified values. Standard error from triplicate analyses was less than $7 \%$ for each element.

All reagents used were Suprapur ${ }^{\mathbb{B}}$ grade and Milli-Q water was used throughout the procedure. Sample manipulation was done in a laminar flow hood.

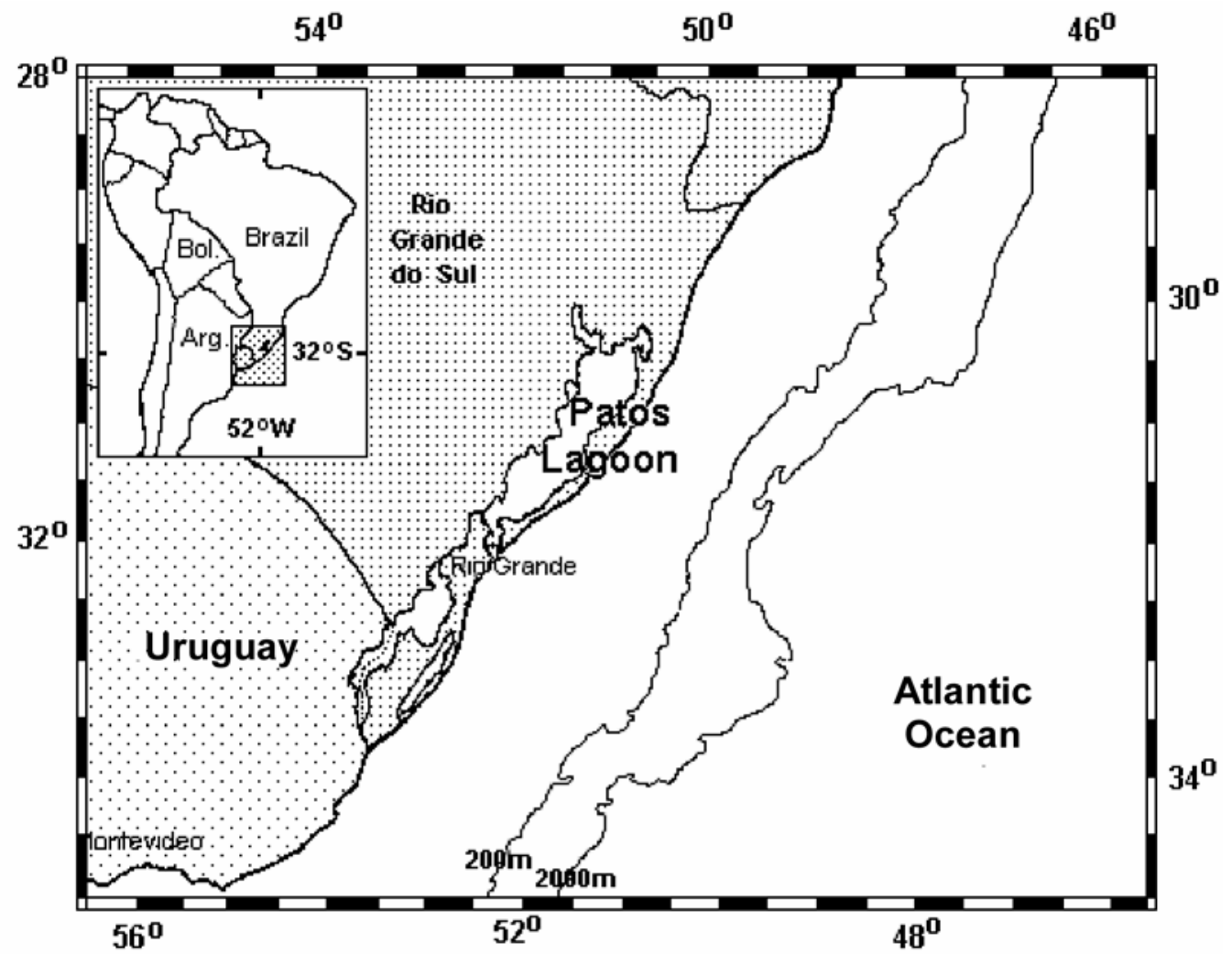

Fig. 1. Sampling Area. 
Table 1. Biological parameters of eight South American fur seals (Arctocephalus australis), collected in August 1999.

\begin{tabular}{ccccc}
\hline \hline $\begin{array}{c}\text { Specimen } \\
\text { No. }\end{array}$ & Sex & $\begin{array}{c}\text { Growth } \\
\text { Stage }\end{array}$ & $\begin{array}{c}\text { Length } \\
(\mathrm{cm})\end{array}$ & $\begin{array}{c}\text { Weight } \\
(\mathrm{kg})\end{array}$ \\
\hline 1 & female & immature & 77.4 & 7.1 \\
2 & female & immature & 91.7 & 5.95 \\
3 & male & immature & 81.7 & 7.5 \\
4 & female & immature & 125.9 & 20 \\
5 & female & immature & 93.9 & 11 \\
6 & male & immature & 102.5 & 6.3 \\
7 & female & immature & 76.4 & 16 \\
8 & male & immature & 72.1 & 6.85 \\
\hline
\end{tabular}

\section{Results ANd Discussion}

The need to Establish Regional Background Level

Since no other studies are available for Arctocephalus australis, the data were compared (Table 2) with Arctocephalus philippii (Island Chile), Arctocephalus gazelle (Antarctic fur seal, Bird Island) and Arctocephalus pusillus (South Eastern Australia) (SEPULVEDA et al., 1997). $\mathrm{Hg}$ and $\mathrm{Cd}$ in the livers of the pups in Chile and Australia showed lower values than those obtained in our study. Surprisingly, the $\mathrm{Cd}$ and $\mathrm{Hg}$ levels found in Antarctic fur seal (Arctocephalus gazelle) were much higher than those in our study. In addition, the concentrations of $\mathrm{Hg}$ and $\mathrm{Cd}$ in the Arctocephalus gazelle (Bird Island) are around 3 and 20 times higher than in Arctocephalus philippii (Island Chile), respectively (SEPULVEDA et al.,1997).

It is well known that the contaminant data generated by various programs in Antarctica and Alaska were primarily designed to establish a baseline database on concentrations in selected species of marine mammals. Based on studies conducted over the last decade (the above-mentioned Arctocephalus species of Antarctica, Chile and Australia have also confirmed this) mammals of remote areas have been found to have relatively high levels of certain contaminants in their tissues. This may be explained by naturally high levels of these elements, plus specific metabolic peculiarities (BECKER, 2000).

This present study shows that further work needs to be carried out to establish the natural baseline levels of many trace elements for marine mammal species. Moreover, specific organisms that exist in different regions have no similarity to mammals in other remote areas.

There is also confusion relating to threshold values. According to Eisler (1985), levels of Cd in the liver or kidney higher than $10 \mu \mathrm{g} / \mathrm{g}$ ww, indicate possible contamination of the organism. Honda et al. (1985) report renal problems when concentrations higher than $20 \mu \mathrm{g} / \mathrm{g}$ ww of $\mathrm{Cd}$ are found in the liver. Other studies have found high levels of Cd (up to 400) in the liver and kidney, due to feeding habits (MARCHOVECHIO et al., 1990).

Table 2. Levels of Trace metals in Heart (H), Liver (L) and Kidney (K) of immature South American fur Seal (range, $\mu \mathrm{g} \cdot \mathrm{g}^{-1}$ wet weight).

\begin{tabular}{|c|c|c|c|c|c|c|c|c|c|c|}
\hline \multirow{2}{*}{$\begin{array}{c}\text { Tissue } \\
\mathrm{H}\end{array}$} & \multicolumn{2}{|c|}{$\mathrm{Hg}$ range } & \multicolumn{2}{|c|}{$\mathrm{Cu}$ range } & \multicolumn{2}{|c|}{ Cd range } & \multicolumn{2}{|c|}{ Ag range } & \multicolumn{2}{|c|}{$\mathrm{Pb}$ range } \\
\hline & 0.006 & 0.775 & 2.07 & 3.96 & 0.14 & 1.00 & 0.001 & 0.016 & 0.08 & 0.16 \\
\hline $\mathrm{L}$ & 0.319 & 54.22 & 3.78 & 12.82 & 0.16 & 29.48 & 0.012 & 0.277 & 0.075 & 0.28 \\
\hline $\mathrm{K}$ & 0.136 & 1.76 & 3.12 & 6.38 & 0.13 & 44.30 & 0.005 & 0.014 & 0.096 & 0.23 \\
\hline Tissue & \multicolumn{2}{|c|}{ Fe range } & \multicolumn{2}{|c|}{ Mn range } & \multicolumn{2}{|c|}{ Ni range } & \multicolumn{2}{|c|}{ Cr range } & \multicolumn{2}{|c|}{$\mathrm{Zn}$ range } \\
\hline $\mathrm{H}$ & 87.42 & 131.99 & $\leq 0.01$ & $\leq 0.01$ & 0.11 & 0.17 & 0.46 & 0.75 & 18.74 & 30.08 \\
\hline $\mathrm{L}$ & 191.64 & 404.04 & 4.07 & 10.45 & 0.09 & 0.17 & 1.10 & 2.04 & 42.48 & 149.13 \\
\hline $\mathrm{K}$ & 62.86 & 115.58 & 0.62 & 1.34 & 0.10 & 0.15 & 0.43 & 0.82 & 45.96 & 108.33 \\
\hline
\end{tabular}


The questions: What is the best approach? Is there any specifically regional or local approach?

This study seems to indicate that the criterion for indicating heavy metal contamination in the organism might be the increased metal content in respect to its local natural background. The establishment of a natural regional baseline value for a specific tissue is not an easy task, as has been mentioned above, but in accordance with our understanding finding the anthropogenic contribution within a given region may be the best approach.

\section{Normalizing Data Procedure}

Since metals from natural and anthropogenic sources accumulate together, it is difficult to determine what proportion in the organism is natural and what is anthropogenic. As has already been shown, there are anthropogenic input and natural metal loads in different environments that may vary by several orders, depending on the geographical location. It is essential, therefore, to normalize the data on the effects of the natural variability of other both biotic and abiotic factors. This approach is unique for marine organisms. Although geochemical normalization has been applied with success for metal concentrations of suspended matter and sediments (NIENCHESKI et al., 1994; NIENCHESKI; BAUMGARTEN, 2000), there is significant justification for the adoption of both approaches:

- Similarly the "Analytical Quality Control Chart" (UNEP, 1995), that provides guidelines for data quality evaluation in environmental chemistry, the purpose of which is to monitor the quality of an ongoing process, will be used to establish a higher and a lower limit beyond which the organisms indicate contamination or low uptake of a certain element, respectively. It is, therefore, important to consider the mean value in a specific organ of all the organisms of the same species studied, and which have a relatively low level of metal concentration, as an initial regional baseline level. Such organisms might be assumed to be uncontaminated in as much as their concentration values are the lowest found in the region. If a factor of 10 is introduced to account for the biotic and abiotic variation effect on the local baseline value, it is therefore likely that comparable organisms in this region are significantly contaminated. Such information would allow an immediate rough assessment of the degree of contamination and its spatial distribution. As the number of organisms studied increases and a better regional database is established, a new factor could be better evaluated.

The background value could be very useful for the assessment of the bioaccumulation capacity of any organ. Regarding our data, the accumulations of non-essential elements $(\mathrm{Cd}$ and $\mathrm{Hg})$ in the heart were lower in concentration than in the other two organs. The study will ascertain if the metal concentration in the heart reflects the same relative bioaccumulation behavior as for the liver and kidneys. The established mean value of a certain organ will be used to normalize data on the same organ. Simply by the division of measured values by the mean baseline value will the preconcentration coefficients be obtained (Table 4).

The lowest concentration values in the three organs were found in organisms 1, 2, 3, 6 and 8 . The data indicate that they were not exposed to a contaminated environment, consequently their mean value might be considered as a reference for the appropriate background value of the region. The summarized ratio values between the lowest and highest concentrations of $\mathrm{Cd}$ and $\mathrm{Hg}$ found in the three organs of contaminated organisms with the respective mean concentration values for the same organ may be found in Table 3. For $\mathrm{Hg}$, the highest normalizing bioaccumulation capacity is observed in the liver and heart, with respective preconcentration coefficients of 76.3 and 43.2. Although the absolute concentration values are higher in the kidneys than in the heart, the kidney preconcentration coefficient for $\mathrm{Hg}$ gave a resulting 8.7, almost five times lower than that for the heart.

Table 3. Ratio between the Range (the lowest and highest values in the group of contaminated organisms) and Mean concentration values of assumed uncontaminated group ( $\mathrm{mg} / \mathrm{kg} \mathrm{ww})$.

\begin{tabular}{ccccccc}
\hline \hline Organ & Range (R) & Mean (M) & $\mathrm{R} / \mathrm{M}$ & Range (R) & Mean (M) & $\mathrm{R} / \mathrm{M}$ \\
& $\mathrm{Cd}$ & $\mathrm{Cd}$ & $\mathrm{Cd}$ & $\mathrm{Hg}$ & $\mathrm{Hg}$ & $\mathrm{Hg}$ \\
\hline Liver & $15.8-29.5$ & 0.23 & $68.5-128.1$ & $9.8-54.2$ & 0.71 & $13.8-76.3$ \\
Kidney & $27.6-44.3$ & 0.226 & $121.7-$ & $0.88-1.77$ & 0.20 & $4.4-8.6$ \\
& & & 195.3 & & & $18.3-43.1$ \\
Heart & $0.57-1.0$ & 0.19 & $2.97-5.2$ & $0.33-0.775$ & 0.018 & 18 \\
\hline
\end{tabular}


Concerning $\mathrm{Cd}$, for the heart, liver and kidneys the preconcentration coefficients were 5.2 , 128.1 and 195.3, respectively. The kidneys showed the highest bioaccumulation capacity.

Many authors use the liver and kidney metal data, even for $\mathrm{Hg}$, because of the high concentrations found in them, thus making analysis easier. This study demonstrates that the heart shows even lower concentrations of $\mathrm{Hg}$ than do the kidneys, so perhaps it would be a better bioindicator organ than the kidneys, and more appropriate for use in monitoring investigations.

\section{Reference Metal Normalization}

It is known that $\mathrm{Fe}$ is an essential element and is abundant in organisms. Fe might be considered "conservative" having relatively uniform concentration in a specific organ of a group of the same species. It compensates for the changes in the input rates of various factors, or variations in aquatic environment, consequently $\mathrm{Fe}$ might be used as a normalizing element. Our proposed approach is widely used in geochemical data normalization procedures (LORING; RANTALA, 1992). After the construction of the scattergram of $\mathrm{Cd}$ or $\mathrm{Hg}$ versus $\mathrm{Fe}$, a regression line with a $95 \%$ confidence band is drawn to define the natural biochemical population of $\mathrm{Cd}$ or $\mathrm{Hg}$ (or any other metal) in its relation to the normalizer element $\mathrm{Fe}$ in the specific organ. The coefficient band of $95 \%$ indicates that the points falling within the prediction interval belong to the normal population and those outside to an anomalous population. In order to use such a scattergram any outlier values of the data set representing the natural biometal population should be removed.

Although, in our study, few data are available, a very significant improvement of correlation coefficient is observed after three outlier values are removed from our data set (three contaminated organisms might be considered as outliers). The data in Table 4 demonstrate that five cases out of six, in which low or negative correlations occur, are converted into positive ones (up to 0.69 ) by removing the contaminated organisms.

As it was difficult to find any outlier for the other metals, all the results of the organisms have been considered for the calculations of correlations with $\mathrm{Fe}$ (Table 4). $\mathrm{Cr}, \mathrm{Pb}, \mathrm{Zn}$ and $\mathrm{Ni}$ (except liver for $\mathrm{Zn}$ and $\mathrm{Ni}$ ) showed particularly close correlations.

\section{Conclusion}

It has thus again been confirmed that both liver and kidneys can be used as good bioindicators for metal contamination. The liver showed the highest levels of all metals, although the kidneys showed the highest for $\mathrm{Cd}$ concentration.

By using a normalizing procedure it was concluded that for $\mathrm{Hg}$, the liver and the heart showed better bioindicator capacities, while for $\mathrm{Cd}$, the kidney and liver showed such capacities. The establishment of a regional background baseline is the best approach for comparing the data. Iron may be used as a normalizing element, in order to define the regional natural biochemical population of the metals.

Further studies and additional experimental data will contribute to the confirmation of the proposed interpretation from the statistical standpoint.

Table. 4. Normalization by Fe (Correlation coefficients).

\begin{tabular}{cccc}
\hline \hline Tissue & Heart & Liver & Kidney \\
\hline $\mathrm{Fe}: \mathrm{Cd}, 8$ organisms & 0.26 & -0.1 & -0.12 \\
$\mathrm{Fe}: \mathrm{Cd}, 5$ organisms & 0.65 & 0.69 & 0.65 \\
$\mathrm{Fe}: \mathrm{Hg}$, 8 organisms & -0.108 & -0.35 & -0.35 \\
$\mathrm{Fe}: \mathrm{Hg}$, 5 organisms & -0.20 & 0.42 & 0.64 \\
$\mathrm{Fe}: \mathrm{Cr}, 8$ organisms & 0.41 & 0.81 & 0.72 \\
$\mathrm{Fe}: \mathrm{Ni}, 8$ organisms & 0.39 & 0.05 & 0.67 \\
$\mathrm{Fe}: \mathrm{Pb}, 8$ organisms & 0.29 & 0.59 & 0.48 \\
$\mathrm{Fe}: \mathrm{Zn}, 8$ organisms & 0.78 & -0.33 & 0.54 \\
$\mathrm{Fe}: \mathrm{Cu}, 8$ organisms & 0.38 & 0.28 & 0.54 \\
$\mathrm{Fe}: \mathrm{Mn}, 8$ organisms & & 0.27 & 0.25 \\
\hline
\end{tabular}




\section{ACKNOWLEDGEMENTS}

The authors wish to thank Vanderlen Miranda, Lucia Bohmer, Denise Garcia and Idel Milani for their assistance in field sampling and analyses. We also thank Debbie Wells for her critical English review of the manuscript. This work was supported in part by the Programa PVE 2006 - CAPES and $\mathrm{CNPq}$ (Grants 552715/2005-0 and 305375/20067).

\section{REFERENCES}

BECKER, P. R. Concentration of chlorinated hydrocarbons and heavy metals in Alaska Arctic marine mammals. Mar. Pollut. Bull., v. 40, n. 10, p. 819-829, 2000.

EISLER, R. Cadmium hazards to fish, wildlife and invertebrates: a synoptic review. U.S. Fish Wildl. Serv. biol. Repts, v. 85, n. $1.2,1985.46$ p.

FAO, Mammals in the seas. Rome, 1979. Fisheries Series, n. 5 , v. II.

HONDA, F.; MIN, B. Y.; TATSUKAWA, R. Heavy metal distribution in organs and tissues of the eastern great white Egretta alba modesta. Bull. environ. Contamin. Toxicol., v. 35, p. 781-789, 1985.

LIMA, M.; PÁEZ, E. Growth and reproductive patterns in the South American fur seal. J. Mammal., v. 76 , n. 4, p. 1249 - 1255, 1995.

LIMA, M.; PAEZ, E. Demography and population dynamics of South American fur seals. J. Mammal., v. 78, n. 3, p. 914-920, 1997.

MAJLUF, P. Timing of births and juvenile mortality in the South American fur seal in Peru. J. Zool. .v. 227, p. 367-383, 1992.
MARCOVECCHIO, J.; MORENO, V.; BATISTA, R.; GERPE, M.; RODRIGUEZ, D. Tissue distribution of heavy metals in small cetaceans from southwestern Atlantic Ocean. Mar. Pollut. Bull. , v. 21, n. 6, p. 299304, 1990.

M.E.S.L., I.A.E.A. Standard Operating Procedures. Monaco, 1997.

LORING, D. H.; RANTALA, R. T. Earth-Sci. Rev., v. 32, p. 235-283, 1992.

NIENCHESKI, L. F.; WINDOM, H.; SMITH, R. Distribution of particulate trace metal in Patos Lagoon Estuary (Brazil). Mar. Pollut. Bull., v. 28, n. 2, p. 96102, 1994.

NIENCHESKI, L. F.; BAUMGARTEN, M. G. Distribution of particulate trace metals in surrounding waters of Rio Grande City (Brazil). Special Issue: State of Brazilian Aquatic Ecosystems. Aquat. Ecosystem Health Mgmt., v. 3, n. 4, p. 515-520, 2000.

SEPULVEDA, M.; OCHOA-ACUNA, H.; SUNDLOF, F. S. Heavy metal concentrations in Juan Fernandez Fur Seals (artocephalus philippii). Mar. Pollut. Bull., v. 34, n. 8, p. 663-665, 1997.

TANABE, S.; SUNG, J. K.; CHOI, D.Y., BABA, N., KIYOTA, M., YOSHIDA, K.; TATSUKAWA, R. Persistent organochlorine residues in northern fur seal from the Pacific coast of Japan since 1971. Environ. Pollut. v. 85, p. 305-314, 1994.

UNEP. Manual for the geochemical analyses of marine sediments and suspended particulate matter. Reference Methods for Marine Pollution Studies n. 63., 1995. 74 p.

(Manuscript received 13 November 2007; revised 14 April 2008; accepted 15 August 2008) 